\title{
Porgera Joint Venture's Presence in the Southern Highlands Province
}

\section{Kai Lavu}

The Porgera Joint Venture (PJV) operates an open pit gold mine at Porgera, in Enga Province. The principal partner in the PJV is Placer (PNG) Pty Ltd, a subsidiary of Canadian mining company Placer Dome Inc. Mineral Resources Enga Pty Ltd, which represents the Enga provincial government and landholders, holds ten per cent equity in PJV. Although the Porgera mine is located in Enga Province, power lines to the mine cut across SHP, and disgruntled landowners in the SHP have on a number of occasions cut down pylons and damaged lines carrying electricity to the mine site, bringing mining operations to a standstill.

PJV has held talks with local communities and with the national government in attempts to address the problems associated with their grievances.

\section{The PJV presence}

The PJV has a high voltage electricity transmission line, $78 \mathrm{~km}$ in length, situated within a 60 metre wide legally-granted easement. Regrowth in the easement is generally cleared to a 30-metre width, on a regular basis using locally hired labour.

In the absence of available suitable government officers, PJV employees carried out the land investigation for the granting of the easement. This was done over a twelve-month period including field surveys.

The transmission line consists of overhead conductors supported as required by single-legged pylons with four stay-wires per pylon. There are some 228 pylons along the route.

\section{Environmental impact}

Where there was existing forest, this has been cleared to an average width of 30 metres. Additional areas were cleared as required for construction (helipads, camps, etc.). Compensation, as per the Papua New Guinea valuer general's schedule (approximately K13,000 per hectare at 2003 values) was paid to identified owners. The original construction would have been disruptive to local fauna but its present impact is minimal. In populated areas, subsistence gardens were affected and compensation paid to identified owners according to the valuer general's schedule (approximately K35,000 per hectare at 2003 values).

Pylons are secured on a concrete pad, as are the stay wires. These are within a 10 metre $\mathrm{x} 10$ metre 'footprint' which is considered to be 'lost land' for the life 
of the transmission line. Overhead inspections of the line are made by helicopter on a monthly basis with some accompanying noise factor.

\section{Community impact}

Prior to the construction of the power line, the communities living along the route had established flexible arrangements regarding land usage, and while land issues did lead to violence from time to time, most conflicts could be resolved amicably. Construction meant that there was an inflow of cash for labour. This created some conflicts as people expected to be hired to work on their own land, and there were some disputes over boundaries and ownership. Similarly, there was an inflow of cash from compensation. Within the settled areas there were no immediate problems, as the money flowed to those who owned the improvements (gardens, houses, etc.) and such ownership was clearly established. Within the forested areas conflicts of ownership did arise as land usage in these areas is very complicated and there were no established boundaries. The cash flow was sufficient to appease most parties, as there was enough to go around and the disputes, while not settled, were put aside. The PJV took the boundaries established in the land investigation report as correct.

After construction was finalised the cash flow dried up. From then until today what cash enters the local economy comes from the payment of annual occupation fees (easement rent at about K40 per hectare) and ad hoc payments for labour to carry out underline clearing. This is a small amount in absolute terms but relative to per capita income in the Tari basin at present it is a significant sum, and has led to a very large number of disputes regarding land boundaries and who is entitled to payments. Where the people were able to resolve disputes amicably before, this has changed by virtue of money being involved. There is now antagonism amongst many of the communities that previously lived in relative harmony.

In the settled areas the people were encouraged to replant subsistence gardens within the easement so as to minimise the impact of the transmission line. The presence of a residential population also meant that there were large numbers of unpaid local security personnel who sought to prevent any untoward actions that may have led to the line being damaged.

In the forested areas local fauna returned very quickly after construction. In the lower reaches, the easement became a well-established foot track. This was not the case in the higher ground as the terrain is too rugged for direct line walking and the people used the traditionally established foot tracks. 


\section{What is required (from a resource developer's viewpoint)}

\section{Normal government services to be available to people}

With access to government services, community development can take place. Education, health, agricultural extension, business development, and so on all lead to an improvement in living standards. Energy is directed towards constructive activities.

A resource developer can play a major role in this regard by being a good neighbour and providing assistance in many ways. The danger is that assistance can be taken for granted and government planners begin to assume that the developer will take over the responsibility for all community work in the area upon which it impacts. The expectation levels of the community can very quickly become excessive.

\section{Access to a competent legal system}

The process of developing a resource will inevitably lead to disputes, between the community and the developer, and within the community itself. Nearly all disputes begin as very minor, however if they are not addressed promptly they grow in magnitude. Village-based systems such as the village court work extremely well when proper training and adequate supervision are provided. The next pertinent level for most resource development disputes is the district land court, which takes care of nearly all cases that village courts cannot resolve. The requirement of a competent legal system includes a well trained, disciplined and equipped police presence. Once again the developer can be a good neighbour by offering suitable assistance, but the same caveats apply.

Without a competent legal system in place, the resource developer is left to try to work through issues with the people. This is a no win situation as nothing is binding and disaffected parties will ignore any resolution reached.

When disputes grow in magnitude serious repercussions can arise. The disruption of power supply to the Porgera mine by criminal activities in the Mt Be area during the three years after a dispute arose could well have been averted if a functioning legal service had been available to the disputants. That no legal action was taken against the perpetrators was a major factor in the developments that caused the mine to be closed for three months.

\section{Institutions to function as expected}

When members of a community go to a village aid post they expect to find the orderly present and medicines available. The same applies to other government services in the rural sector. The role of the public servant in maintaining the supply of goods and services is vital. For government services to function well, district and provincial public servants must be well trained, ethical, competent 
and responsible. Unfortunately, training and support is almost totally lacking in SHP and this leads to a collapse of the services in the rural areas.

Resource developers can aid and assist government offices at the local level in a number of ways but there is no way that a resource developer can undertake to retrain a public service.

\section{District and local-level government plans to be established}

For many reasons it is desirable for medium-term plans to be in place at district and council levels. A resource developer can tap into these plans, if they are available, and help maximise the benefits. All developers have a community assistance program of some kind. With a close relationship with the local administration, great achievements can be obtained in a collaborative manner; local ownership is created and greater care is taken of the asset.

\section{The Office of Planning and Rural Development}

The Office of Planning holds the authority to accept or veto proposals made under the Tax Credit Scheme (TCS). The TCS has been operating for many years and has been well accepted. There is commitment to the construction and maintenance of institutional buildings in both urban and rural areas. Developers gain much in the way of public goodwill from the TCS and it is an extremely efficient way of obtaining what become state-owned assets. The TCS is a vital tool in establishing rapport with affected communities. A difficulty has arisen, however, in that there appear to be no firm guidelines for developers to follow when preparing proposals. Lengthy delays are incurred obtaining approvals. Often communities are aware that proposals have been submitted and become impatient when projects do not proceed. There is an urgent need to have this situation examined. Clear and firm policies and guidelines must be established in order for the TCS to function.

\section{Donor agencies to utilise resource developers' knowledge}

Numerous donor agencies operate in Papua New Guinea. They usually operate at a high level of efficiency and deliver many essential services to the country. Resource developers are long-term residents and accumulate a profound knowledge of their impacted areas. Donor agencies should be encouraged to tap into this knowledge to maximise the affect of proposed projects and programs. This needs to be managed in such a way that the credit for the project is not hijacked by the developer.

These are only a few of the 'requirements' that a developer would like to have in place within a resource area. The most important of these are the first three points raised above. Without the availability of the basic services at community level, the developer becomes the target for unreasonable and unacceptable demands. Without the availability of a competent legal system, 
the developer is exposed to unreasonable demands followed by criminal activities to take what is wanted. Personal risk levels to employees become unacceptable. Without the availability of a competent government system in place at district level, the developer is expected to assume the role of the government, a position which is untenable.

The remaining points are not, of course, a necessary requirement for resource development. However, they are powerful tools in establishing a strong collaborative relationship with the impacted communities, providing the lynchpin that links developer and the community and greatly enhances the sustainability of the resource development.

\section{Conclusion}

At the present time, however, none of the above exists. The resource developers carry out their business virtually from crisis to crisis, using their own manpower to overcome the problems. Major road blockages, power line damage, and shutdowns are becoming more frequent. Most landowner groups causing these problems are simply reacting to a lack of government services and lack of government attention to dispute resolution. The resource developer supplies funds to the national government through taxes and royalties. By shutting down the resource, the cash flow is halted. Then the government is forced to act. However many commitments are made and never honoured. Agreements are reached but not carried out. Each time this occurs the frustration amongst the landowners grows. Unless positive, continuous, and sustainable steps are taken to re-establish good, solid ethical governance throughout the province, the maintenance of any long-term development of resources in the Southern Highlands Province will be doubtful.

The Huli people have expressed their viewpoint in a simple way: 'We are tolerant people and traditionally we count the number of times that we are given bad answers. We count them one, two, three, up to 14 . When the count reaches 15 we must react and react with violence. That is our way'. The count is currently hovering around the 12/13 mark. 